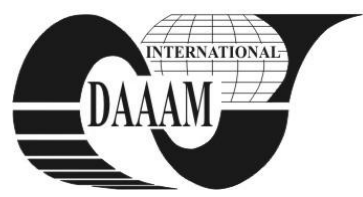

\title{
EFFECT OF INCREASING FEED SPEED ON THE MACHINED SURFACE INTEGRITY
}

\author{
PETRKOVSKA, L[enka]; HRIBNAK, D[avid]; PETRU, J[ana] \& CEPOVA, L[enka]
}

\begin{abstract}
Paper describes the issue of high speed milling. There is describe an experiment, it was performed on high speed machining center at the Technical university of Poznan and thanks to CEEPUS program.

At the experiment were used material ASP 2023 (tool steel) and two different cutters. First tool had three edges and the other had four edges. Diameter of both millers was the same. These tools have been performed several cuts, and there were gradually increased feed speed and cutting speed. These individual sections were consequently investigated. There were measured surface roughness and residual stress. At the roughness was measured roughness $R a$ and $R z$. To determine the residual stress mas used method of Barkhausen noise.

Key words: HSC, surface integrity, barkhausen noise, high speed milling
\end{abstract}

\section{INTRODUCTION}

The integrity of the machined surface depends on its properties described and can be described by the following parameters:

- surface topography (geometric characteristic of the surface profile),

- structural changes having occurred in the surface layer,

- degree, depth and nature of the material hardening,

- significance, magnitude and direction of the residual stresses. (Zeleny, J. 2000)

HS machining can be characterized by the fact that the area of the primary plastic deformation is reduced to a narrow band remaining in the shear plane; this contraction is due to the impact of high-speed cutting. The plastic deformation is quite small and nearly does not reach below the plane of cutting. The magnitude of material hardening thus depends solely on the tertiary plastic deformation. Due to the impact of HS technology, the intensity of the surface layer hardening will be decreased, while the depth of the hardened layer is very low. (Skopecek et al., 2005)

To verify these facts were conducted the experiments. At the experiment were milling steel surface in term of conventional and high-speed parameters. There were verifies roughness and surface residual stress. (Dobransky, 2007)

\section{EXPERIMENT CONDITIONS}

For this experiment was used material ASP 2023. It is noncobalt high speed steel produced by powder metallurgy. This steel is suitable for high-performance tools for cold working.

\begin{tabular}{|c|c|c|c|c|c|}
\hline Material marking & \multicolumn{5}{|c|}{ ASP 2023 } \\
\hline \multirow{2}{*}{ Chemical composition [\%] } & $\mathrm{C}$ & $\mathrm{Cr}$ & Mo & $\mathrm{W}$ & $\mathrm{V}$ \\
\cline { 2 - 6 } & 1,30 & 4,20 & 5,00 & 6,40 & 3,10 \\
\hline Method production & \multicolumn{5}{|c|}{ Powder metallurgy } \\
\hline Product & \multicolumn{5}{|c|}{ Flat stick } \\
\hline
\end{tabular}

Tab. 1. Chemical composition of ASP 2023
It was made on the cutting machine Universal milling centrum DMU 60monoBLOCK from DECKEL MAHO Company. This universal milling machine has high stiffness, dynamics and precision. It is intended for productive machining the most.

For the machining were choosen two cutters. The first tool was four-edges carbide cutter with $30^{\circ}$ helix pitch is suitable for high-productive machining. Tool diameter is $18 \mathrm{~mm}$. Its marking is F4AJ1800ADN30. This cutter is suitable for finish milling. The second tool was trhee-edges carbide cutter with $30^{\circ}$ helix pitch. With rigid bodies and structures are used for high-productive machining. Tool diameter is $18 \mathrm{~mm}$. This cutter is used for finishing milling. Its marking is F3AH1800ADL30. Today has been customary that the cutting tool to use part of the coating. In this particular case the tools use a PVD coating with layers of TiN, TiCN, TiC.

As cutting parameters for the first tool were chosen those:

- $\mathrm{a}_{\mathrm{p}}=0,25 \mathrm{~mm}, \mathrm{f}_{\mathrm{z}}=0,25 \mathrm{~mm}$

- $\mathrm{v}_{\mathrm{f}}=10 \mathrm{~m} \cdot \mathrm{min}^{-1}, \mathrm{n}=10000 \mathrm{~min}^{-1}, \mathrm{v}_{\mathrm{c}}=566 \mathrm{~m} \cdot \mathrm{min}^{-1}$

- $\mathrm{v}_{\mathrm{f}}=15 \mathrm{~m} \cdot \mathrm{min}^{-1}, \mathrm{n}=15000 \mathrm{~min}^{-1}, \mathrm{v}_{\mathrm{c}}=848 \mathrm{~m} \cdot \mathrm{min}^{-1}$

- $\mathrm{v}_{\mathrm{f}}=20 \mathrm{~m} \cdot \mathrm{min}^{-1}, \mathrm{n}=20000 \mathrm{~min}^{-1}, \mathrm{v}_{\mathrm{c}}=1131 \mathrm{~m} \cdot \mathrm{min}^{-1}$

- $\mathrm{v}_{\mathrm{f}}=24 \mathrm{~m} \cdot \mathrm{min}^{-1}, \mathrm{n}=24000 \mathrm{~min}^{-1}, \mathrm{v}_{\mathrm{c}}=1357 \mathrm{~m} \cdot \mathrm{min}^{-1}$.

As cutting parameters for the second tool were chosen those:

- $\mathrm{a}_{\mathrm{p}}=0,25 \mathrm{~mm}, \mathrm{f}_{\mathrm{z}}=0,33 \mathrm{~mm}$

- $\mathrm{v}_{\mathrm{f}}=1 \mathrm{~m} \cdot \mathrm{min}^{-1}, \mathrm{n}=1000 \mathrm{~min}^{-1}, \mathrm{v}_{\mathrm{c}}=57 \mathrm{~m} \cdot \mathrm{min}^{-1}$

- $\mathrm{v}_{\mathrm{f}}=5 \mathrm{~m} \cdot \mathrm{min}^{-1}, \mathrm{n}=5000 \mathrm{~min}^{-1}, \mathrm{v}_{\mathrm{c}}=283 \mathrm{~m} \cdot \mathrm{min}^{-1}$

- $\mathrm{v}_{\mathrm{f}}=10 \mathrm{~m} \cdot \mathrm{min}^{-1}, \mathrm{n}=10000 \mathrm{~min}^{-1}, \mathrm{v}_{\mathrm{c}}=566 \mathrm{~m} \cdot \mathrm{min}^{-1}$

- $\mathrm{v}_{\mathrm{f}}=15 \mathrm{~m} \cdot \mathrm{min}^{-1}, \mathrm{n}=15000 \mathrm{~min}^{-1}, \mathrm{v}_{\mathrm{c}}=848 \mathrm{~m} \cdot \mathrm{min}^{-1}$

- $\mathrm{v}_{\mathrm{f}}=20 \mathrm{~m} \cdot \mathrm{min}^{-1}, \mathrm{n}=20000 \mathrm{~min}^{-1}, \mathrm{v}_{\mathrm{c}}=1131 \mathrm{~m} \cdot \mathrm{min}^{-1}$

- $\mathrm{v}_{\mathrm{f}}=24 \mathrm{~m} \cdot \mathrm{min}^{-1}, \mathrm{n}=24000 \mathrm{~min}^{-1}, \mathrm{v}_{\mathrm{c}}=1357 \mathrm{~m} \cdot \mathrm{min}^{-1}$.

\section{EVALUATION OF SURACE INTEGRITY}

\subsection{Surface roughness}

To evaluate the surface roughness of the parameters were chosen to reflect the needs of practice. The material were carried monitored parameters $\mathrm{Ra}$ - arithmetic average of the absolute deviations in the profile of the fundamental length $(\mu \mathrm{m})$ and $\mathrm{Rz}$ - the highest level of inequality roughness profile determined by the distance between the studs line profile and line profile in the recesses of the fundamental length $(\mu \mathrm{m})$. Each machined surface was measured 10 times, in the longitudinal direction - the direction of the displacement vector and transvense - perpendicular to the direction of movement.

Measurement of surface roughness was carried out touch (point-contact) devise Surtest SJ-401 from MITUTOYO Company. Evaluation of texture, waviness and many other parameters is possible to do on this devise according to various national and international standards. 


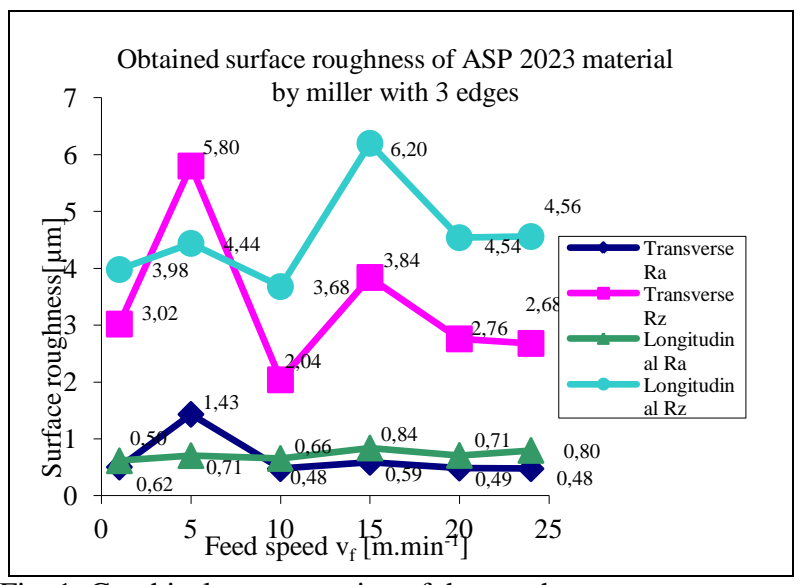

Fig. 1. Graphical representation of the roughness

The graph on the figure 1 shows that the feed speed $\mathrm{v}_{\mathrm{f}}=15 \mathrm{~m} \cdot \mathrm{min}^{-1}$ is achieved by the worst surface roughness parameters. After exceeding the speed when it gets into the high-speed milling, the roughness parameters better.

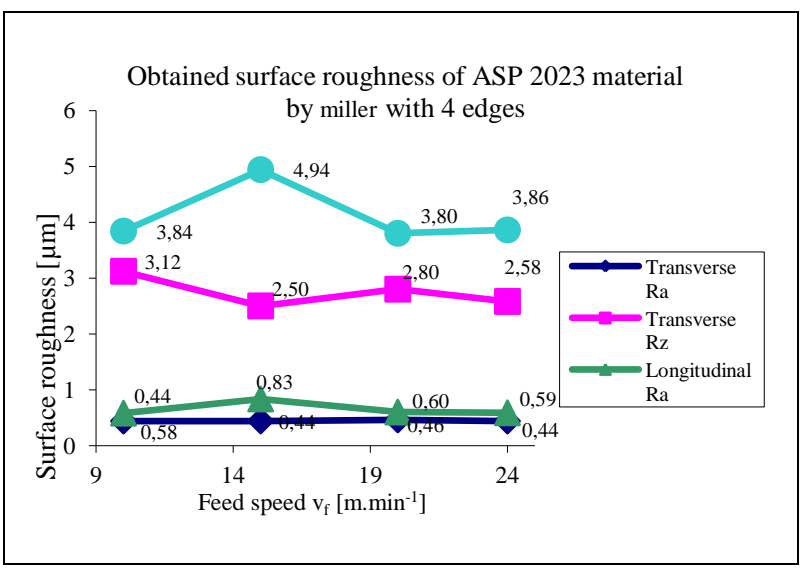

Fig. 2. Graphical representation of the roughness

The graph on figure 2 shows that the feed speed $\mathrm{v}_{\mathrm{f}}=15 \mathrm{~m} \cdot \mathrm{min}^{-1}$ is achieved by the worst surface roughness parameters. After exceeding the speed roughness parameters are significantly better. The high-speed milling machine si achieved faster times, and as shown in the picture and has a very good surface roughness parameters. This finding confirms the theoretical assumptions. (Petrkovska \& Brychta, 2008)

\subsection{Evaluation of residual stress}

Determine the size of the residual stress can be carried out in many ways. To evaluate the surface of experiments was chosen method of detecting residual stress in close proximity to the surface. The magnetoelastic method based on the use Barkhausen noise is non-destructive and therefore are often used primarily for evaluation of surface in the automotive and aerospace industries. (Mickelson, 2007)

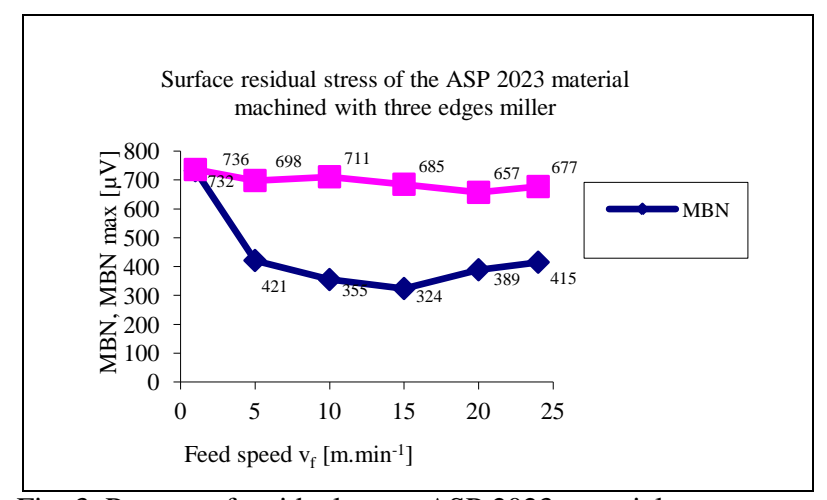

Fig. 3. Process of residual stress ASP 2023 material

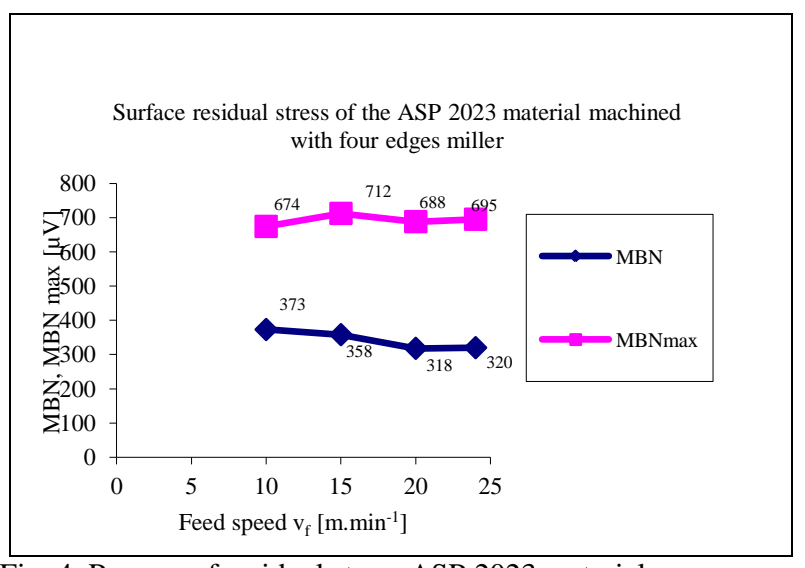

Fig. 4. Process of residual stress ASP 2023 material

The graph shows the negative effects of low machining parameters on surface residual stresses. MBN best values are achieved when using $\mathrm{v}_{\mathrm{f}}=15 \mathrm{~m} \cdot \mathrm{min}^{-1}$. It can be inferred that the chosen milling conditions there was no significant structural changes.

In this experiment it was omitted low parameters of machining. This restriction of experiment was performed because of tool wear. The values that were achieved can be derived by using the positive influence of shunting high speed milling. (Petrkovska \& Brychta, 2008)

\section{CONCLUSION}

The main aim of this paper is analysis of influence relevant parameters of machining by tool with define cutting geometry on the surface integrity. Effort was analyse of some surface integrity parameters of conventional milling and high speed milling.

The measurement results show that with increasing the cutting speed does not cause significantly increased surface of the roughness $\mathrm{Ra}$ and $\mathrm{Rz}$. As a new knowledge can be result of measuring residual stress, when it was shown that the material injected high speed milling were no significant surface tension.

This problem can be extended to other research sphere especially to do experiments with other materials with hardened surface or use other tools with bigger diameter and more cutting edges.

\section{REFERENCES}

Dobransky, J. (2007). Observation for production process capacity by injection moulding, Scientific bulletin, 17.-19. May, 2007, Baia Mare, Romania, ISSN 1224-3264, Nicolae UNGUREANU (Ed. Universitatea de Nord din Baia Mare), p. 197- 201

Mickelson, D. (2007). Guide to Hard Milling and High Speed Machining, Industrial Press Inc., ISBN 978-0-8311-3319-1, New York

Petrkovska, L.; Brychta, J. (2008). Cutting parameters at highspeed cutting, Scientific Bulletin, 21.-23. 2008, Baia Mare, Romania, vol. VII., no. 1, ISSN 1224-3264, Nicolae UNGUREANU (Ed. Universitatea de Nord din Baia Mare), p. $381-384$

Skopecek, T. et al. (2005). Základy vysokorychlostního obrábění-HSC. Publisher Západočeská univerzita v Plzni, 2005. ISBN 80-7043-344-2, (Ed. Herkner), Place of Publication Západočeská univrzita v Plzni, Czech republic

Zeleny, J. (2000). Vysokorychlostní obrábění, MM průmyslové spectrum, Special Edition, (06/2000) ISSN 1224-2572 